\title{
Haaga-Helia
}

ammattikorkeakoulu

HUOM! Tämä on alkuperäisen artikkelin rinnakkaistallenne. Rinnakkaistallenne saattaa erota alkuperäisestä sivutukseltaan ja painoasultaan.

Käytä viittauksessa alkuperäistä lähdettä:

Paesbrugghe, B., Vuori, J. and Kock, H. (2021), "Selling to enabled purchasers: the effect of perceived supply risk and profit impact on the buyer-seller interaction", Journal of Business \& Industrial Marketing, Vol. ahead-of-print No. ahead-of-print. https://doi.org/10.1108/JBIM-05-2019$\underline{0252}$

PLEASE NOTE! This in an electronic self-archived version of the original article. This reprint may differ from the original in pagination and typographic detail.

Please cite the original version:

Paesbrugghe, B., Vuori, J. and Kock, H. (2021), "Selling to enabled purchasers: the effect of perceived supply risk and profit impact on the buyer-seller interaction", Journal of Business \& Industrial Marketing, Vol. ahead-of-print No. ahead-of-print. https://doi.org/10.1108/JBIM-05-20190252

(C) 2021 CC BY-NC 4.0 


\section{Selling to Enabled Purchasers: The Effect of Perceived Supply Risk and Profit Impact on the Buyer-Seller Interaction}

\begin{tabular}{|r|l|}
\hline Journal: & Journal of Business and Industrial Marketing \\
\hline Manuscript ID & JBIM-05-2019-0252.R5 \\
\hline Manuscript Type: & Original Article \\
\hline Keywords: & $\begin{array}{l}\text { Buyer-seller interaction, Kraljic Purchasing Portfolio Matrix, Direct } \\
\text { Marketing, Personal selling, Channel Management }\end{array}$ \\
\hline \multicolumn{2}{|l}{} \\
\hline
\end{tabular}

\section{SCHOLARONEm \\ Manuscripts}




\section{Selling to Enabled Purchasers: The Effect of Perceived Supply Risk and Profit Impact on the Buyer-Seller Interaction.}

\section{Introduction}

Customer centricity is a recent trend. However, considerable misalignment still exists between buyers' needs and how selling companies try to create value for their buyers. In particular, selling companies often adopt a selling focus without incorporating the buyers' needs (Paesbrugghe et al., 2017; Verbeke et al., 2011). These needs are grounded by the buyers' desire to reduce the total risk exposure for the buying organization, as well as the necessity to control the full profit impact of any purchasing decision (Kraljic, 1983).

Scholars and practitioners advocate that selling companies should create value for buyers by involving their salespeople in the selling process as early as possible (Dixon and Adamson, 2011). By doing so, selling companies can quickly identify the buyers' needs and present a suitable solution for those needs. However, Gartner (2018) reported that buyers only spend 17\% of their time with salespeople via different communication channels. This statistic calls for a new approach wherein personal selling is balanced with efforts via digital marketing channels. At the same time, salespeople recognize the importance of being customer-centric, but they are unaware of the standard metrics used by their prospective buyers, such as the Kraljic (1983) purchasing portfolio matrix.

One recent change on the buying side is that buyers now have more internal decisionmaking power than ever before (Flint et al., 2011). Moreover, a recent trend is the increased strategic focus on procurement (Rust et al., 2002). Buyers are more often making judgments about the future efficiencies and effectiveness of their supplying (selling) companies (Möller and Törrönen, 2003). 
In addition, the buyers' sourcing journey has evolved such that the buyers' focus has moved toward the most important buying decisions (Tassabehji and Moorhouse, 2008). Fueled by new waves of digitalization, business customers have greater access to a broader set of information to hasten their buying decision (Moncrief, 2017). This results in strengthened buying power (Wiersema, 2013) as well as more demanding and better-informed buyers (Verbeke et al., 2011).

Salespeople, however, are challenged by the question of how they can be seen as effective and efficient throughout the buying process. Furthermore, research poses the question of whether salespeople have to abandon their role as a basic information channel and whether they can create value for their customers by challenging their current ways of doing business (Adamson et al., 2012).

In a Business-to-Business (B2B) selling context, the value placed on information communication by the salesperson leads to positive experiences for buyers (Agnihotri et al., 2009, 2016). Moreover, meeting the buyers' information needs is one of the basis for business success (Constantinides and Fountain, 2008).

Despite the changes that have taken place on the buyers' side over past decades, research on how selling companies should match their channel strategy to the buyers' information needs is remarkably limited. This paper addresses the buyers' needs when sourcing new products or services and presents how digital marketing and personal selling channels should be implemented to increase the returns on sales force resources.

The paper is organized as follows. Based on the Kraljic (1983) purchasing portfolio matrix and a thematic analysis of 35 in-depth interviews with B2B buyers, this study investigates buyers' sourcing needs and addresses the research question "How does the perceived supply risk 
influence the desired personal selling or digital marketing channels approach?" Next, we address the research question "How should B2B selling companies adapt their channel strategy depending on how buyers classify the sales offering?"

The outcome of our research extends the B2B value creation literature by: (i) addressing the call for research on how to combine digital communication with personal communication in industrial selling (Constantides and Fountain, 2008; Cummins et al., 2016; Foster, 2005); and (ii) by proposing an adaptive channel strategy for selling companies based on buyers' classifications of the sales offering. Thus, this research aligns the channel strategy with the purchaser's efficiency needs that are grounded on the type of sales offering. More specifically, this study compares the digital marketing channel approach with personal selling approach based on buyers' demands to facilitate their buying process. This paper also addresses the call of Paesbrugghe et al. (2018) on how we can better understand the purchasing function.

Furthermore, this article contributes to the buyer-seller literature by highlighting when personal selling or digital marketing channels are valued as (in)effective in the buying process. Personal selling is advised when buyers categorize the sales offering as high risk, whereas digital marketing channels should be put forward for sales offerings that are categorized as low risk. The coupled framework will guide commercial directors on how they can manage the empowered B2B buyer by adapting their channel strategy.

\section{Literature review}

Portfolio models for purchasing are considered to be excellent for organizing information and classifying suppliers (Olsen and Ellram, 1997). These models are increasingly being used by purchasing professionals and top management (Nellore and Söderquist, 2000). The Kraljic (1983) 
purchasing portfolio matrix, in particular, is the most widely used purchasing matrix in practice (e.g., Gelderman and van Weele, 2003; Lamming and Harrison, 2001). It is also used as a reference for academic purposes for discussing purchases (Caniëls and Gelderman, 2005; Dubois and Pedersen, 2002; Formentini et al., 2019). The two-by-two matrix categorizes the profit and supply-risk impact of the purchased goods or services on the buying company. The profit and supply-risk axes result in four product/service quadrants: leverage, strategic, non-critical, and bottleneck products (Kraljic, 1983).

Leverage products have high profit impact but represent low supply risk. Considering the example of a bakery, the regular flour for making bread would be considered as a leverage product. The bakery spends a considerable amount of money on this ingredient (profit impact), but there are many suppliers of flour (supply risk). The appointed purchasing strategy is to increase the level of competition among the suppliers because of the numerous alternatives available.

Strategic products can only be sourced from a small set of suppliers and generally have considerable impact on production and delivery costs. As an example, the purchase of a large data center by a cloud-based software provider largely impacts the profitability of the firm, however, only a handful of suppliers are available who can manage very large projects. Here, the best-suited purchasing strategy is to collaborate or partner with the supplier.

The third product category in the Kraljic (1983) purchasing portfolio matrix comprises the non-critical products that are characterized by low supply and low financial-impact risks. An example of a non-critical product would be a bouquet of flowers at the reception desk of a construction firm. Here the supplier's strategy is to reduce the supplier base to simplify the buying process. 
Finally, bottleneck products have a relatively smaller influence on the company financial position compared with other products, but these bottleneck products are associated with a higher-than-average supply risk, such as the specialty hops used to produce a particular beer. Without the hops, the brewer cannot brew the beer: at the same time, the cost of the hops relative to the brewery's turnover is low. The buyer of bottleneck products will continuously search for alternative products or methods, such as by keeping a higher stock of hops to reduce its supplier dependency (Kraljic, 1983).

The contemporary buyer-seller environment presents salespeople with the challenge of finding ways to overcome the current ineffectiveness of many previously effective sales approaches (Dixon and Tanner, 2012; Paesbrugghe et al., 2020). The effectiveness of many sales approaches has been questioned based on the on-going paradigm shift in the purchasing domain (Spina et al., 2013). Purchasing-based changes have had, and are expected to continue having, a tremendous influence on the buying process (Ostrom et al., 2015; Paesbrugghe et al., 2017). Yet, the different roles of buyer-seller relationships in the marketing and sales domain are either studied from the buyer's perspective (e.g., Lapierre, 2000; Parasuraman, 1997; Ravald and Grönroos, 1996; Ulaga and Eggert, 2006) or the seller's perspective (e.g., Möller and Törrönen, 2003; Simpson et al., 2001; Walter et al., 2001). Buying companies, however, are gradually shifting power to the purchasing and buying function (e.g., Cousins et al., 2006).

Purchasers have gained more budget responsibility, reaching $50-90 \%$ of the cost of goods sold, to the extent that the purchasing and buying function is rapidly becoming a critical resource for the buying firm (Sheth et al., 2009). At the same time, procurement has progressed from being seen as an administrative cost center to being seen as a strategic pillar for the organization (e.g., Töytäri and Rajala, 2015). Purchasers are thus gaining support within their organization, so 
much so that the future success of the sales function will heavily depend on the liaison with these “empowered buyers" (Spina et al., 2013). However, only a few studies examine the changes in the buying process and the impact of these changes on the sales function (Paesbrugghe et al., 2018). Despite calls to further examine the buyer side of the buyer-seller relationship (Williams and Plouffe, 2007; Paesbrugghe et al., 2017), the literature examining the effects of the evolution and practices of the purchasing function. The impact of these effects on the organization of digital marketing channels and personal selling is still lacking.

Contemporary research suggests that the purchasing function has needs that are distinct from those of the other members of the buying center. This entails the need for sales strategies to explicitly recognize the role of the purchasing function. Moreover, the purchasing function cannot be seen as static in the selling process. This calls for selling companies to reshape their sales approaches given the empowerment and changes occurring in buyer behavior owing to digitalization.

\section{The Buyers' Information Sourcing Journey and Information Consumption}

The strategic focus on purchasing is an expansion of procurement's previous role, which was associated more with cost cutting and efficiency, and served more of a value-enhancing function than as a strategic resource (McIvor et al., 1997). The shift to the strategic role of procurement is attributable, in part, to the availability of information and the ability to exploit a mix of information during the sourcing process for new purchases (Moriarty and Spekman, 1984; Webster, 1991). This has been made possible largely owing to the investments of supplier firms on digital marketing channels such as websites and social media (Karjaluoto et al., 2015a).

During this sourcing process for new purchases, purchasers assess the completeness of the information and knowledge they need and the information and knowledge they already possess. 
This completeness is determined, and any deficiencies are compared with the availability and accessibility of the required knowledge and information. Today, business customers are increasingly empowered by information, which has become more accessible via digital marketing channels (Karjaluoto et al., 2015b; Lamberton and Stephen, 2016; Verona et al., 2006).

To improve their customer relationships, companies often turn to technology-driven initiatives. Successful implementation of technology may enable companies to more successfully interact and engage with their customers (Verhoef et al., 2010). However, B2B firms still struggle to understand the dynamics of customer interactions. Most B2B marketing literature on digital media is restricted to the use of social media (e.g., Karjaluoto et al., 2015a, 2015b; Kumar et al., 2016).

Studies on B2B buyers' online and offline preferences remain scarce. Lanzolla and Frankort (2016) examined how offline signals affect buyers' online behavior in B2B marketplaces. They found that visible offline signals, such as geographic presence or legal status, affect the likelihood of buyers to contact sellers online.

In their quantitative study, Schoenherr and Mabert (2011) compared online and offline purchasing in $\mathrm{B} 2 \mathrm{~B}$ markets in the case of a multi-item request for quotation (RFQ). They compared online reverse auctions (suppliers competing against one another) and offline purchasing along the dimensions of purchase importance, supply market availability, future orientation, and item specification difficulty. One of their main findings was that offline purchasing is likely to be chosen when the purchase is highly important, whereas auctions are preferred when the purchase is not as important because they allow more suppliers to participate in the bidding process. No differences were detected between the future orientation of the buyer and the item specification difficulty. 


\section{Sales Approaches to Cope with Buyers' Needs}

DeVincentis and Rackham (1998) present a model wherein strategies are matched to buyers by viewing two dimensions: investments made by the supplier and investments made by the buyer. This results in three sales approach classifications: transactional, consultative and enterprise sales. Despite its two-way view, the model focuses on how the salesforce should allocate their resources based on buyers' valuations: that is, how often and in what kind of breadth buyers want to meet the salesforce. However, the model does not consider other dimensions.

DeVincentis and Rackham (1998) state that sales managers should distinguish their go-tomarket strategies based on the perceived importance between the buying and selling companies. Personal selling is only advised for strategic buyers. The researchers propose "cheaper channels" rather than personal selling for transactional sales. Viio and Grönroos (2016) indicate that the buyer-seller relationship orientation affects sales-process adaptation. Business engagement can be either buyer-driven, seller-driven, product-based, or value-based depending on the buyers' and sellers' relational approach.

Telleffsen (2002) examines commitment in B2B relationships from the purchasing managers' perspective. He suggests that a purchasing manager forms stronger bonds with the suppliers who are better able to satisfy both the buying firm's organizational needs and the purchasing manager's personal needs or desire for personal gains, such as security, power, or prestige. The study also proposes that purchasing managers will be more influenced by personal gains rather than organizational need fulfillment. The implications for marketing are that stronger bonds with purchasing managers can be developed by offering benefit bundles that address both organizational and personal gains. 
The current study differs from those previously published and adds to the literature by addressing the strategic importance and perceived risk to the buyer. It suggests a differentiated channels approach, digital marketing channel or personal selling, for selling companies depending on the classification of the sales offering by the buyer. For example, Bunn and Liu (1996) found that the risk dimensions - purchase importance and task uncertainty - create significant differences in the buying process. They suggest different selling strategies, but they do not consider different channel approaches, nor do they base their research on the buyer's efficiency goals. Thus, a holistic view of how to use digital marketing channels and personal selling is missing in the current literature.

This study first highlights the different sourcing needs of buyers, which are based on the buyers' classification of the sales offering in the Kraljic (1983) purchasing portfolio matrix. This then serves to appropriately match the buyers' risk trade-off and hence the desired channel strategy from the selling organization.

\section{Methodology}

For this study, we interviewed thirty-five people who represented a wide range of companies of different sizes and from different industries. The study was designed in such a way that the interviewees were prospective customers of selling companies that had agreed to cooperate with the research team by giving contact information of prospective customers who were in the early stages of their buying journey. These selling companies represented the following industries: furniture manufacturing, management consulting, security, healthcare, telecommunications, and Information Technology (IT) services and solutions. The interviewees had an average of nine 
years of experience in purchasing and the sample included 21 men and 14 women. A full sample description can be found in Appendix 1.

After been given contact information of prospective customers of the selling company, the researchers approached them with an interview request. If permission was granted, the interview was conducted either face-to-face, by telephone, or via Voice over Internet protocol (VoIP). The interviews lasted 46 minutes on average (range: 25 to 104 minutes). During the interview, an interview guide (Appendix 2) was used to prompt the interviewees to share their experiences as B2B buyers in general, and after that, to reflect on the early stages of their buying journey with the selling company, with a particular emphasis on the used digital and personal sales channels. All interviews were audiotaped and transcribed verbatim.

The data analysis was based on inductive coding, which means that the data was not forced to fit into any pre-existing theory (Christians and Carey, 1989). The coding guidelines for thematic analysis were adopted from Brown and Clarke (2014). The researchers analyzed the first set of interviews by familiarizing themselves with the transcribed texts, followed by a discussion of the contents within the research team. The resulting output served as the basis for the initial coding chart. This initial output was then used to analyze the first ten interviews conducted. The three members of the research team individually coded these ten interviews to iterate the coding chart, followed by an in-depth comparison of the used codes. A group discussion helped to align the coding team to improve the coding objectives and to familiarize everyone with the coding rules. This process took place during the first research visit of one of the researchers at the home university of the two other researchers This helped to make sure that the researchers were applying the same codes for similar subcategories, as well as helping to improve inter-coder reliability. 
Through several rounds of iterative coding with the rest of the interview transcripts and constant comparison within the coding team, 19 coding categories were finally identified and were placed under three main themes. The coding chart with quote examples is in Appendix 3.

The first main theme, importance of accessible information, combined the subcategories that dealt with the buyer's needs to access information to progress over the first steps of the buyer journey. The subcategories that merged into this main theme were the 24/7 availability of information; easy to use channels of information; multichannel availability; responsiveness of the sales organization (chat, automated email, phone call); and delivery tracking and ordering system. The second main theme, the importance of comprehensive information, summarized the subcategories of the buyer's desired level for complete information for a given product or service. The subcategories that merged into this main theme were the financial situation; contact information; pricing; references provided by the supplier; peer references online and offline; sustainability; product or service features; and location.

The third main theme that arose was the attitude towards digital channels and personal selling. This main theme arose by merging the subcategories on the buyers' beliefs and attitudes towards the use of digital marketing channels or by having personal selling touchpoints. Under the umbrella of this main theme, we had the following subcategory codes: use of digital marketing channels; shortlisting process; point of face-to-face meeting.

Finally, to put the three main themes into context with respect to the buyer's perceived risk or uncertainty, the research team categorized the 35 buying situations using the Kraljic (1983) purchasing portfolio matrix. The process of plotting the buying situations into the four categories of the Kraljic purchasing portfolio matrix was done on the basis of the buyers' descriptions of their purchasing needs expressed during the interviews, and by following the 
guidelines of Gelderman and van Weele (2003) and Olsen and Ellram (1997). This allocation was done individually by the same group of coders, followed by a group discussion. Six buying situations were discussed in a subsequent group discussion to make sure the allocation matched the objectives of the Kraljic model until all researchers agreed on the classification of the buyer and his/her buying situation. The process of agreeing upon the allocation of the buying situations took place during a second research visit of one of the researchers at the home university of the two other researchers. As a result, 3 buyers and their associated buying situations were allocated to the quadrant of strategic purchases, 1 buyer to the quadrant of bottleneck purchases, 10 buyers to the quadrant of non-critical purchases, and 21 buyers and their buying situations to the leverage quadrant.

The analysis proceeded by examining the similarities within and differences across the four quadrants. The process was conducted by two researchers to ensure the correct interpretation of the data as well as to increase comprehensibility (Burla et al., 2008; Schreier, 2012). During this round of analysis, the third researcher of the team individually conducted the analysis of the four product groups and obtained the same findings.

Finally, a member check (Lincoln and Guba 1985) was conducted to evaluate the validity of the research. A member check is considered an important part of validating qualitative research. Birt et al. (2016) found that the member check approach was very accurate in checking the validity in qualitative research by presenting the findings to the participants. For this study, we deployed a member check with an in-depth assignment on the findings of this research with two different groups (fourteen and eighteen participants) in an executive Master class. This helped the research team to verify and better interpret the interview findings. The goal of this member check was to check the validity of our research findings within the professional contexts 
of the executive audiences. We presented the findings of this study as subjective findings and we asked the participants to check and interpret the subjectivity of these findings to their current contexts. More precisely, the executive audiences were asked to categorize their sales offering according to the Kraljic purchasing portfolio matrix, and to assess their buyer-seller relationships with the current channel design structures. The executives confirmed that the buyer point of view following this approach would strengthen their positioning with their buyers, and lead to a better allocation of their resources.

\section{Results}

In this section, we discuss the impact of the efficient sourcing journey of buyers that corresponds to the Kraljic (1983) purchasing portfolio matrix. We also describe the main themes that emerged from the analyses: (i) accessibility of information; (ii) comprehensiveness of information; and (iii) attitudes towards digital marketing channels and personal selling. Next, we discuss how the purchasing focus and the associated buyer's efficiency need affect the desired sales communication approach. Finally, propositions for the sales function are presented.

Our analysis showed that purchasing efficiency needs were high for leverage products and very high for non-critical products, whereas the need to increase the efficiency or, in other words, reduce the handling of the purchase was low for bottleneck products and even lower for strategic products. The objective of the purchasing process for non-critical and leverage products is to maximize the sourcing efficiency and reduce the buyer's handling. This can be done, for example, by moving these purchases to a fully automated purchasing system. In the following section, we discuss the three pillars of buyer sourcing efficiency. 


\section{Accessibility of Information}

The interviewees highlighted an evolution in the quality of the messages brought by selling companies. The buyer now has better access to information that is relevant to his/her buying journey. As illustrated by the following quote from an interviewee, digitalization has transformed buyers' dependence on the information provided by the seller:

“Let's say that since 2010, I have an option of informing myself in a relevant way through social media. Before 2010 I only had Google, and before that I only had salespeople. So, salespeople could do whatever they want because I had no alternative. Google came. I could inform myself, but I couldn't have conversations. Social media came in addition to Google, and now I can have conversations in a relevant way because the information is part of the conversation." (Buyer of leverage products)

However, there are differences between how B2B buyers representing different quadrants of the Kraljic matrix value the accessibility of information in the early stages of their buying journey. The interview material suggests that the accessibility of information online is of vital importance to the buyers of non-critical or leverage products in the early stages of the buying journey. Buyers start by looking for information on potential suppliers, and they want to find it through digital marketing channels, as can be noted from the following quotes:

"For this kind of purchases, I would like to have a website that compares all the offers." (Buyer of non-critical products) "Findability of a product's features online is very important." (Buyer of non-critical products)

"I'll start searching for information purely [on] the Internet and see what's available." (Buyer of leverage products) 
A buyer of leverage products in the early stages of his/her sourcing journey states the following about searching information via digital marketing channels:

"I'm really at that stage that [the need is] becoming concrete only in the fall. I'm actually just checking out what kinds of actors and what types of issues exist." (Buyer of leverage products)

Buyers of bottleneck and strategic products did not mention digital marketing channels as being important in accessing information.

"A part of that information can be found online. Not all information of course, but only a part. I am at roughly twenty per cent of making my buying decision before I contact the selling company for the first time. If you are looking for risk reduction, then you need to exclude risks as much as possible. When you are accountable for these risks, then you definitely need to know who you are dealing with before you continue the purchasing journey." (Buyer of bottleneck products)

"If you are in B2B and you use LinkedIn, you might be subscribed to their channels. But this is not the channel I will use when I need something." (Buyer of strategic products)

\section{Comprehensiveness of Information}

Salespeople are no longer relied upon for basic information because buyers conduct independent information searches. However, the importance of comprehensive information via digital marketing channels varies depending on the buyer's location in the Kraljic matrix. A participant in the bottleneck products quadrant states his/her expectations of the seller companies regarding the role of information:

"Okay, they're digital. Are they able to facilitate the questions I have throughout the
buying journey on specific topics to better understand my problem and what part of my 
problem will be solved by their solution? How am I going to reassure myself that I am selecting the right solution? What is the risk perception of the future compared with the price at which I'm buying? And as long as that is not in balance, I'm not ready to buy. So, the more important the thing is, the longer will be the last part of my buying journey, which is education. The company that is guiding me in the most optimal way is the company that will create most credibility along the way. " (Buyer of bottleneck products) Another interviewee expressed wanting to improve his/her understanding by meeting face-to-face before using all online information:

"If it's extremely impactful and/or I'm not very knowledgeable about it, I will get in touch with companies way earlier in the buying cycle to get a better understanding. Because if I don't, if I'm not knowledgeable, then to what extent is the Internet going to help me to find the right information? I might be seeking the wrong things because I'm not knowledgeable on how to solve what I need to solve." (Buyer of strategic products)

Some buyers collect information on a regular basis. Two exemplar interviewees shared what kind of information they prefer:

"I get newsletters from the larger operators and of course some smaller too. And I follow certain blogs." (Buyer of leverage products)

Another buyer pointed out the following:

"I'm not very analytical... If [the information] is not interesting enough, I'll skip it. ... Reference cases, I usually read them with great enthusiasm." (Buyer of leverage products)

Company webpages have their task, as another buyer states, 
"When I look for products, I visit [company] webpages because then you're able to compare prices. But if I'm looking for services, many other sources of information than the webpages matter. Usually, webpages are quite bad for describing services." (Buyer of leverage products)

Buyers of bottleneck and strategic products view webpages to get reassurance of a company's capabilities, as the following quotation shows:

"I look at their websites, and I think, okay, this company shows me the information to prove that they are knowledgeable enough or they have the capabilities to make this successful." (Buyer of strategic products) “... I glanced at these [webpages] quite quickly and sent a message. And if I remember correctly, they did not create any feelings, so they must have been working. They must have functioned; I would remember if it had been particularly difficult. The pages must have been ok." (Buyer of strategic products)

In the next section, we zoom in on the buyers' readiness to have a personal selling conversation.

\section{Channel Preferences: Attitudes Towards Digital Marketing Channels and Personal Selling}

The desired communication channels - digital marketing channels or personal selling - clearly differ depending on which quadrant in the Kraljic matrix the bought product is located. In the case of non-critical products, online communication is preferred, as the following informant states:

"It does not matter so much. Look, if the supply risk is on the low end, it makes perfect sense to buy online." (Buyer of non-critical products)

This view is also shared by another buyer: 
"If it's just buying something easy, it is one hundred per cent online. Okay? If the purchase has high impact or there is a relationship needed, then of course I want to at least meet that salesperson if not the person that is going to render the services to us." (Buyer of strategic products)

Another exemplar quote from a different buyer illustrates this idea as follows:

"We only had contact over the phone or maybe through video conferencing. So, we met physically because they are also based in the U.S. For this type of purchase, often it does not matter if you meet the seller or not." (Buyer of leverage products)

Leverage products are shortlisted using digital marketing channels, but face-to-face meetings are favored as the next step, as one participant describes:

"If I am very knowledgeable, then most of my buying time, let us say, will be online. I will inform myself online; I will go all the way to my shortlist and then I may think, 'Oh, I could maybe invite one or two companies, one or two salespeople to come by, to present me and then take a decision." (Buyer of leverage products)

Likewise, "If it's about something small, I'll send a message or inquiry online. But if it's anything more complex, a software solution, etc., I'll call them.... well, right in the beginning, the first meetings. After one or two meetings face-to-face, you can use Skype when you already know each other." (Buyer of leverage products)

Another buyer of solutions appreciates meeting with the experts after shortlisting suppliers: "I don't mind if the whole team comes to meet me in the first or second meeting." (Buyer of leverage products) 
Meeting face-to-face is of vital importance when buying bottleneck or strategic products, as two interviewees describe:

"I like to do the research online, but there comes a point when you want to talk to someone, start asking some questions, and testing what you read and what you understood. So, it is like double checking whether what you found online is still correct or and can the salesperson provide a still better solution?" (Buyer of strategic products)

Likewise,

"I really wanted to meet the salespeople of this company. Not over the phone and not via email. You have to look them in the eyes to see how trustworthy their offer is, to ask follow-up questions, and to get convinced. Yes, that is really face-to-face." (Buyer of bottleneck products)

The results of the study are illustrated in Table 1 . They show clear implications for selling companies based on the categorization of the sales offering in the Kraljic (1983) purchasing portfolio matrix. The critical question for selling companies that want to build on the above classification and implications is limited to the interpretation of how their offering is categorized by the buying firm.

\section{[Insert Table 1 about here]}

An identical sales presentation for all four quadrants, from non-critical to strategic products, would not be effective because the classification in the buying matrix is specific to the buying company and the sales offering. For example, cleaning products will be categorized differently by buyers in a cleaning firm (most likely as strategic products) than by buyers working for a finance company (most likely as non-critical products) and would thus require a different sales approach. 


\section{Discussion}

This study of B2B buyers' perceptions of different channel approaches contributes to answering the pressing question in the sales domain of how selling companies can better address the buyers' needs. The suggested channel approaches in this paper are centered on the buyers' needs in terms of the availability and accessibility of information for a given buying situation and thus on the buyers' openness to engage in personal selling.

The buyers interviewed in this study call for a particular channel approach based on how they categorize the sales offer in the Kraljic (1983) purchasing portfolio matrix (see Table 1). First, the buyers of non-critical products seek to have all the information they need to make a buying decision. Given the low supply risk for the buying organization, buyers want to increase their buying efficiency. In other words, they want an automated and easy purchasing process without the intervention of a salesperson. Therefore, selling companies should try to trigger an automated, digital marketing channel approach.

For leverage products, the buyers want to improve their buying efficiency. From the buyers' point of view, the main difference between leverage and non-critical products is that leverage products have a relatively high impact on the total expenditure of the buying company. For these types of purchases, buyers value having accessible and complete information. The results of the buyers' preferred channel approach for leverage products are distinct in the following way. For new purchases, the buyer first follows a structured shortlisting process that favors personal selling. Thus, selling companies should design digital marketing channels in such a way that all shortlisting qualifications are easily accessible online. Moreover, they should create "action buttons" to take the conversation to personal selling. Once the buyer-seller relationship is 
established, the selling organization should opt for less expensive digital marketing channels to serve the buyer.

The third and fourth types of purchases in the Kraljic (1983) purchasing portfolio matrix, bottleneck and strategic products, imply a high supply risk for the buying company. The interviewed buyers state that trust is an essential qualifier. This confirms the findings of previous studies on the importance of trust and trustworthiness in strategic buyer-seller relationships. Surprisingly, buyers do not require all the necessary information to make a decision for these types of purchases. Moreover, it is of utmost importance for buyers to be able to locate qualifiers online that will lead them to having a personal selling meeting.

Given the high supply risks associated with these purchases, buyers value personal selling and want to assess trustworthiness from the sales side. Moreover, these products are strategic or bottlenecks in nature, therefore, they have to be adapted to the specific industry and buying company needs. Hence, buyers want to examine the adaptability of the selling organization to their specific needs. Buyers also demand innovative capabilities from the selling organization to further reduce the risks associated with these types of purchases. Therefore, we recommend that the sales conversation should be controlled by personal selling as soon as possible so that salespeople can uncover specific company needs and start adding value by matching their offers to those specific needs.

\section{[Insert Table 2 about here]}

\section{Conclusion}

Literature focusing on how B2B selling companies facilitate the buying process of their prospects is limited. This purchaser-focus for salespeople has most recently gained attention in the industrial marketing domain (e.g. Bonney et al., 2019). This study contributes to the literature on 
buyer-seller relationships (e.g., Dwyer et al., 1987) and cross-functional relationship marketing in B2B settings (e.g., Snehota and Hakansson, 1995; Weitz and Bradford, 1999). Moreover, it explores the barriers, usage and perceived benefits for selling companies when using a differentiated channel strategy depending on the classification of the sales offer. The research was conducted among B2B buyers in two countries and reveals some interesting findings.

Further, this research contributes to the adaptive selling literature by introducing initial guidance for selling companies based on how the sales offer is classified by the buyer. Based on this classification, the study sheds light on some of the barriers to the use of digital marketing channels and personal selling. Moreover, this study signals that personal selling is crucial when the sales offer has a perceived supply risk, where not having the product or service might severely damage the company from the buyer's point of view. All buyers (100\%) in our sample preferred personal selling for these types of products and services. This view is a step towards further aligning marketing and sales departments, instead of adopting a silo view on sales research.

For products that entail a high impact on the profit of the buying firm but have a relatively low supply risk (because there are many suppliers in the market), personal selling is advised for the buyers who are conducting a new purchase. Personal selling should be supported by digital marketing channel platforms after the buyer-seller relationship is established, which was highlighted by $57 \%$ of the buyers. The remaining $43 \%$ of the buyers had a strong preference for digital marketing channels because it increased their buying efficiency. Finally, when the product is categorized as non-critical - meaning that there is no perceived supply risk and the impact on the profitability of the buying firm is limited - the selling organization should only focus on 
digital marketing channels. For this type of product, selecting personal selling as a go-to-market approach gives no added value, given that $78 \%$ of buyers preferred digital marketing channels.

\section{Limitations and Future Research}

This paper is subject to some limitations. First, we recognize that there are limitations to the use of the Kraljic matrix (Gelderman and van Weele, 2005). One limitation is that the four quadrants of the Kraljic matrix are not always mutually distinct. In this article, we proposed a differentiated digital marketing channels or personal selling approach based on how buyers categorize the sales offering in the Kraljic (1983) matrix. This limits the validity of our research to the correct use of the Kraljic matrix by the buying organization. This issue might cause a misalignment between our propositions and practice.

Another limitation is related to the generalizability of our results, especially for the organizations that are selling a heterogeneous bundle of products or services to the same customer. Future quantitative studies can expand upon our results.

Finally, it would be an interesting avenue for future research to investigate the buyer-seller relationship where the salesperson reaches out before the buyer had considered that selling firm. We hope this paper will serve as an impetus for the discussion on how a selling company's channel strategies should be adapted to the sourcing needs of B2B buyers. 


\section{References}

Adamson, B., Dixon, M. and Toman, N. (2012), "The end of solution sales", Harvard Business Review, Vol. 90 No. 7, pp. 60-68.

Agnihotri, R., Dingus, R., Hu, M.Y. and Krush, M.T. (2016), "Social media: Influencing customer satisfaction in B2B sales", Industrial Marketing Management, Vol. 53, pp. 172180.

Agnihotri, R., Rapp, A. and Trainor, K. (2009), "Understanding the role of information communication in the buyer-seller exchange process: antecedents and outcomes", Journal of Business and Industrial Marketing, Vol. 24 No. 7, pp. 474-486.

Birt, L., Scott, S., Cavers, D., Campbell, C., and Walter, F. (2016), "Member checking: a tool to enhance trustworthiness or merely a nod to validation?", Qualitative health research, Vol. 26 No. 13, pp. 1802-1811.

Braun, V. and Clarke, V. (2014), "What can "thematic analysis" offer health and wellbeing researchers?", International Journal of Qualitative Studies on Health and Well-Being, Vol. 9, p. 26152.

Bunn, M. D., \& Liu, B. S. C. (1996). Situational risk in organizational buying: A basis for adaptive selling. Industrial Marketing Management, Vol. 25 No. 5, pp. 439-452.

Burla, L., Knierim, B., Barth, K. L., Duetz, M., \& Abel, T. (2008). From the text to coding: Intercoder reliability assessment in qualitative content analysis. Nursing Research, Vol. 57, pp. 113-117.

Caniels, M.C. and Gelderman, C.J. (2005), "Purchasing strategies in the Kraljic matrix-A power and dependence perspective", Journal of Purchasing and Supply Management, Vol. 11 No. 2-3, pp. 141-155.

Christians, C. G., \& Carey, J. W. (1989). The logic and aims of qualitative research. Research methods in mass communication, pp. 354-374.

Constantinides, E. and Fountain, S.J. (2008), "Web 2.0: Conceptual foundations and marketing issues", Journal of Direct, Data and Digital Marketing Practice, Vol. 9 No. 3, pp. 231-244.

Cousins, P.D., Lawson, B., Squire, B. and Squire, B. (2006), "An empirical taxonomy of purchasing functions", International Journal of Operations and Production Management, Vol. 26, pp. 775-794.

Cummins, S., Peltier, J.W. and Dixon, A. (2016), "Omni-channel research framework in the context of personal selling and sales management: A review and research extensions", Journal of Research in Interactive Marketing, Vol. 10 No. 1, pp. 2-16.

DeVincentis, J. R. and Rackham, N. (1998), "Breadth of a Salesman", The McKinsey Quarterly, No. 4, pp. 9-13.

DeVincentis, J. and Rackham, N. (1999), Rethinking the Sales Force: Redefining Selling to Create and Capture Customer Value, McGraw Hill Professional, NY.

Dixon, A.L. and Tanner Jr, J.J.F. (2012), "Transforming selling: Why it is time to think differently about sales research", Journal of Personal Selling and Sales Management, Vol. 32 No. 1, pp. 9-13.

Dixon, M. and Adamson, B. (2011), The challenger sale: Taking control of the customer conversation, Penguin, NY.

Dubois, A. and Pedersen, A. (2002), "Why relationships do not fit into purchasing portfolio models - a comparison between the portfolio and industrial network approaches", European Journal of Purchasing and Supply Management, Vol. 8 No. 1, pp. 35-42. 
Dwyer, F.R., Schurr, P.H. and Oh, S. (1987), "Developing buyer-seller relationships", Journal of Marketing, Vol. 51 No. 2, pp. 11-27.

Flint, D.J., Blocker, C.P. and Boutin Jr, P.J. (2011), "Customer value anticipation, customer satisfaction and loyalty: An empirical examination", Industrial Marketing Management, Vol. 40, pp. 219-230.

Formentini, M., Ellram, L.M., Boem, M. and Da Re, G. (2019), "Finding true north: Design and implementation of a strategic sourcing framework", Industrial Marketing Management, Vol. 77, pp. 182-197.

Foster, T. (2005), "Creating digital value: at the heart of the IEI framework", Journal of Business and Industrial Marketing, Vol. 20 No. 4/5, pp. 245-252.

Gartner (2018), "What sales should know about modern b2b buyers", available at: https://www.gartner.com/smarterwithgartner/what-sales-should-know-about-modern-b2bbuyers/ (accessed 15 September 2019).

Gelderman, C.J. and Van Weele, A.J. (2003), "Handling measurement issues and strategic directions in Kraljic's purchasing portfolio model”, Journal of Purchasing and Supply Management, Vol. 9 No. 5-6, pp. 207-216.

Gelderman, C.J. and Van Weele, A.J. (2005), "Purchasing portfolio models: a critique and update", Journal of Supply Chain Management, Vol. 41 No. 3, pp. 19-28.

Glaser, B.G. and Strauss, A.L. (1967), The Discovery of Grounded Theory. Strategies for Qualitative Research, Wiedenfeld and Nicholson, London.

Karjaluoto, H., Ulkuniemi, P., Keinänen, H. and Kuivalainen, O. (2015a), “Antecedents of social media B2B use in industrial marketing context: customers' view", Journal of Business and Industrial Marketing, Vol. 30 No. 6, pp. 711-722.

Karjaluoto, H., Ulkuniemi, P. and Mustonen, N. (2015b), "The role of digital channels in industrial marketing communications", Journal of Business and Industrial Marketing, Vol. 30 No. 6, pp. 703-710.

Kraljic, P. (1983), "Purchasing must become supply management”, Harvard Business Review, Vol. 61 No. 5, pp. 109-117.

Kumar, A., Bezawada, R., Rishika, R., Janakiraman, R. and Kannan, P. (2016), "From social to sale: The effects of firm-generated content in social media on customer behavior", Journal of Marketing, Vol. 80 No. 1, pp. 7-25.

Lamberton, C. and Stephen, A.T. (2016), "A thematic exploration of digital, social media, and mobile marketing: Research evolution from 2000 to 2015 and an agenda for future inquiry", Journal of Marketing, Vol. 80 No. 6, pp. 146-172.

Lamming, R. and Harrison, D. (2001), "Smaller customers and larger suppliers: the potential for strategic purchasing approach: a case study", in Proceedings of the 10th International IPSERA Conference, pp. 595-610.

Lanzolla, G. and Frankort, H.T. (2016), "The online shadow of offline signals: Which sellers get contacted in online B2B marketplaces?", Academy of Management Journal, Vol. 59 No. 1, pp. 207-231.

Lapierre, J. (2000), "Customer-perceived value in industrial contexts", Journal of Business and Industrial Marketing, Vol. 15 No. 2/3, pp. 122-145.

Lincoln Y, Guba E: Naturalistic inquiry. 1985, Newbury Park: Sage Publications.

McIvor, R., Humphreys, P. and McAleer, E. (1997), "The evolution of the purchasing function", Strategic Change, Vol. 6 No. 3, pp. 165-179. 
Möller, K.K. and Törrönen, P. (2003), “Business suppliers' value creation potential: A capabilitybased analysis", Industrial Marketing Management, Vol. 32 No. 2, pp. 109-118.

Moncrief, W.C. (2017), “Are sales as we know it dying... or merely transforming?", Journal of Personal Selling and Sales Management, Vol. 37 No. 4, pp. 271-279.

Moriarty Jr, R.T. and Spekman, R.E. (1984), “An empirical investigation of the information sources used during the industrial buying process", Journal of Marketing Research, Vol. 21 No. 2, pp. 137-147.

Nellore, R. and Söderquist, K. (2000), "Portfolio approaches to procurement: Analysing the missing link to specifications", Long Range Planning, Vol. 33 No. 2, pp. 245-267.

Olsen, R.F. and Ellram, L.M. (1997), “A portfolio approach to supplier relationships”, Industrial Marketing Management, Vol. 26 No. 2, pp. 101-113.

Ostrom, A.L., Parasuraman, A., Bowen, D.E., Patrício, L. and Voss, C.A. (2015), "Service research priorities in a rapidly changing context", Journal of Service Research, Vol. 18 No. 2, pp. 127-159.

Paesbrugghe, B., Rangarajan, D., Sharma, A., Syam, N. and Jha, S. (2017), "Purchasing-driven sales: Matching sales strategies to the evolution of the purchasing function", Industrial Marketing Management, Vol. 62, pp. 171-184.

Paesbrugghe, B., Sharma, A., Rangarajan, D. and Syam, N. (2018), "Personal selling and the purchasing function: where do we go from here?", Journal of Personal Selling and Sales Management, Vol. 38 No. 1, pp. 123-143.

Paesbrugghe, B., Rangarajan, D., Hochstein, B., \& Sharma, A. (2020), "Evaluation of salespeople by the purchasing function: implications for the evolving role of salespeople", Journal of Personal Selling and Sales Management, Vol. 40 No. 4, pp. 289305.

Parasuraman, A. (1997), "Reflections on gaining competitive advantage through customer value", Journal of the Academy of marketing Science, Vol. 25 No. 2, pp. 154.

Ravald, A. and Grönroos, C. (1996), "The value concept and relationship marketing", European Journal of Marketing, Vol. 30 No. 2, pp. 19-30.

Rust, R.T., Moorman, C. and Dickson, P.R. (2002), "Getting return on quality: revenue expansion, cost reduction, or both?”, Journal of Marketing, Vol. 66, pp. 7-24.

Schoenherr, T. and Mabert, V.A. (2011), "A comparison of online and offline procurement in B2B markets: results from a large-scale survey", International Journal of Production Research, Vol. 49 No. 3, pp. 827-846.

Schreier, M. (2012). Qualitative content analysis in practice. Thousand Oaks, CA: Sage.

Sheth, J.N., Sharma, A. and Iyer, G.R. (2009), "Why integrating purchasing with marketing is both inevitable and beneficial", Industrial Marketing Management, Vol. 38 No. 8, pp. 865871.

Simpson, P.M., Siguaw, J.A. and Baker, T.L. (2001), “A model of value creation: Supplier behaviors and their impact on reseller-perceived value", Industrial Marketing Management, Vol. 30 No. 2, pp. 119-134.

Snehota, I. and Hakansson, H. (1995), Developing relationships in business networks, Routledge, London.

Spina, G., Caniato, F., Luzzini, D. and Ronchi, S. (2013), "Past, present and future trends of purchasing and supply management: An extensive literature review", Industrial Marketing Management, Vol. 42 No. 8, pp. 1202-1212. 
Tassabehji, R. and Moorhous, A. (2008), "The changing role of procurement: Developing professional effectiveness", Journal of Purchasing and Supply Management, Vol. 14 No. 1, pp. 55-68.

Tellefsen, T. (2002), "Commitment in business-to-business relationships: The role of organizational and personal needs", Industrial Marketing Management, Vol. 31 No. 8, pp. 645-652.

Töytäri, P. and Rajala, R. (2015), "Value-based selling: An organizational capability perspective", Industrial Marketing Management, Vol. 45, pp. 101-112.

Ulaga, W. and Eggert, A. (2006), "Value-based differentiation in business relationships: Gaining and sustaining key supplier status", Journal of Marketing, Vol. 70 No. 1, pp. 119-136.

Verbeke, W., Dietz, B. and Verwaal, E. (2011), "Drivers of sales performance: a contemporary meta-analysis. Have salespeople become knowledge brokers?", Journal of the Academy of Marketing Science, Vol. 39 No. 3, pp. 407-428.

Verhoef, P.C., Reinartz, W.J. and Krafft, M. (2010), "Customer engagement as a new perspective in customer management", Journal of Service Research, Vol. 13 No. 3, pp. 247-252.

Verona, G., Prandelli, E. and Sawhney, M. (2006), "Innovation and virtual environments: Towards virtual knowledge brokers", Organization Studies, Vol. 27 No. 6, pp. 765-788.

Viio, P. and Grönroos, C. (2016), "How buyer-seller relationship orientation affects adaptation of sales processes to the buying process", Industrial Marketing Management, Vol. 52, pp. $37-46$.

Walter, A., Ritter, T. and Gemünden, H.G. (2001), "Value creation in buyer-seller relationships: Theoretical considerations and empirical results from a supplier's perspective", Industrial Marketing Management, Vol. 30 No. 4, pp. 365-377.

Webster, C. (1991), "Influences upon consumer expectations of services", Journal of Services Marketing, Vol. 5 No. 1, pp. 5-17.

Weitz, B.A. and Bradford, K.D. (1999), "Personal selling and sales management: A relationship marketing perspective", Journal of the Academy of Marketing Science, Vol. 27 No. 2, p. 241.

Wiersema, F. (2013), "The B2B agenda: The current state of B2B marketing and a look ahead", Industrial Marketing Management, Vol. 4 No. 42, pp. 470-488.

Williams, B.C. and Plouffe, C.R. (2007), “Assessing the evolution of sales knowledge: A 20-year content analysis", Industrial Marketing Management, Vol. 36 No. 4, pp. 408-419. 


\section{Appendix 1: Sample Characteristics}

\begin{tabular}{|c|c|c|c|c|c|c|}
\hline Title & Gender & $\begin{array}{l}\text { Years in } \\
\text { purchasing }\end{array}$ & $\begin{array}{l}\text { Seller company's } \\
\text { line of business }\end{array}$ & $\begin{array}{l}\text { Interviewee's } \\
\text { company's } \\
\text { turnover } \\
\text { (Million Euros) }\end{array}$ & $\begin{array}{l}\text { Interviewee's } \\
\text { company's line } \\
\text { of business } \\
\text { (TOL) }\end{array}$ & $\begin{array}{l}\text { Number of } \\
\text { employees of } \\
\text { interviewee's } \\
\text { company }\end{array}$ \\
\hline $\begin{array}{l}\text { Production } \\
\text { Manager }\end{array}$ & $\mathrm{M}$ & 10 & Security & 17.5 & 18120 & 131 \\
\hline Supply Manager & $\mathrm{M}$ & 4 & Security & 68.8 & 28220 & 1513 \\
\hline $\begin{array}{l}\text { Finance } \\
\text { Manager }\end{array}$ & $\mathrm{M}$ & 2.5 & Security & 19.3 & 56210 & 135 \\
\hline Supply Manager & $\mathrm{M}$ & 1.5 & Security & 124.6 & 41200 & 508 \\
\hline Entrepreneur & $\mathrm{M}$ & 12 & Telecom & n.a. & 73111 & 1 \\
\hline $\begin{array}{l}\text { Managing } \\
\text { Director }\end{array}$ & $\mathrm{M}$ & 26 & Telecom & 0.94 & 81220 & 18 \\
\hline $\begin{array}{l}\text { Technical } \\
\text { Producer }\end{array}$ & $\mathrm{M}$ & 7 & Telecom & 1.2 & 74901 & 15 \\
\hline $\begin{array}{l}\text { Head } \\
\text { Accountant }\end{array}$ & $\mathrm{F}$ & 11 & Telecom & 2.8 & 47642 & 12 \\
\hline $\begin{array}{l}\text { Head of } \\
\text { Financial Admin. }\end{array}$ & $\mathrm{F}$ & 30 & Telecom & 1.6 & 25990 & 15 \\
\hline Design Engineer & $\mathrm{M}$ & n.a & Telecom & 1.5 & 25730 & 19 \\
\hline Office Manager & $\mathrm{F}$ & 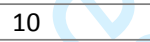 & Telecom & 1.2 & 3991 & 10 \\
\hline Office Manager & $\mathrm{F}$ & 10 & Telecom & 1.9 & 23610 & 12 \\
\hline $\begin{array}{l}\text { Managing } \\
\text { Director }\end{array}$ & $\mathrm{M}$ & 20 & Telecom & 1.4 & 10710 & 9 \\
\hline HR Manager & $M$ & 3.5 & Healthcare & 35.1 & 58142 & 205 \\
\hline Office Manager & $\mathrm{F}$ & 3 & Healthcare & 7.2 & 28950 & 71 \\
\hline $\begin{array}{l}\text { Financial } \\
\text { Director }\end{array}$ & $M$ & 15 & Healthcare & 75.1 & 42220 & 196 \\
\hline Head of Finance & $\mathrm{F}$ & 0.5 & Healthcare & 16.6 & 43330 & 196 \\
\hline $\begin{array}{l}\text { Financial } \\
\text { Director }\end{array}$ & $\mathrm{M}$ & 5 & Healthcare & 7.5 & 82990 & 77 \\
\hline $\begin{array}{l}\text { Business } \\
\text { Controller }\end{array}$ & $\mathrm{F}$ & 15 & Healthcare & 6.9 & 56101 & 80 \\
\hline HR Specialist & $\mathrm{F}$ & 1 & Healthcare & 7 & 46741 & 26 \\
\hline HR Coordinator & $\mathrm{F}$ & 4.5 & Healthcare & 174.1 & 47521 & 262 \\
\hline Purchaser & $M$ & 4 & Furniture & 787.5 & B30110 & 1567 \\
\hline $\begin{array}{l}\text { Purchasing } \\
\text { Manager }\end{array}$ & $\mathrm{M}$ & 3 & Furniture & 9.8 & 64990 & 58 \\
\hline $\begin{array}{l}\text { Maintenance } \\
\text { Manager }\end{array}$ & $\mathrm{M}$ & $5+$ & Furniture & 37.1 & 30110 & 535 \\
\hline $\begin{array}{l}\text { Managing } \\
\text { Director }\end{array}$ & $\mathrm{F}$ & 10 & Furniture & 796 & 70220 & 11 \\
\hline $\begin{array}{l}\text { Director, Patient } \\
\text { Care }\end{array}$ & $\mathrm{F}$ & 3 & IT services & 12.6 & 86909 & 49 \\
\hline $\begin{array}{l}\text { Infor. Systems } \\
\text { Manager }\end{array}$ & $M$ & 25 & IT services & 14.4 & 25620 & 77 \\
\hline $\begin{array}{l}\text { Staff } \\
\text { Coordinator }\end{array}$ & $\mathrm{M}$ & 3 & IT services & 470 & 60201 & 3421 \\
\hline Specialist & $M$ & 2 & IT services & 10.4 & 62020 & 89 \\
\hline Director & $\mathrm{F}$ & 5 & IT services & 737 & 65121 & 1044 \\
\hline Senior Manager & $\mathrm{F}$ & 15 & IT services & 172.6 & 96011 & 958 \\
\hline $\begin{array}{l}\text { Service Delivery } \\
\text { Manager }\end{array}$ & $M$ & 1 & IT services & 203 & 33200 & 754 \\
\hline $\begin{array}{l}\text { Head of } \\
\text { Marketing }\end{array}$ & $\mathrm{F}$ & 9 & IT services & 87900 & 10 & 150000 \\
\hline $\begin{array}{l}\text { Head of } \\
\text { Marketing and } \\
\text { Digital. }\end{array}$ & $\mathrm{M}$ & n.a. & Consultating & 1400 & 65121 & 8000 \\
\hline $\begin{array}{l}\text { Program } \\
\text { Manager }\end{array}$ & $\mathrm{M}$ & 10 & IT services & 8630 & 46140 & 37200 \\
\hline
\end{tabular}




\section{Appendix 2. Interview protocol}

\section{General questions}

What is your role in procurement? What are your buying responsibilities for your company? What is your role in procurement? What are your buying responsibilities for your company? Which of the following roles would describe your position the best: An expert, an influencer, a coordinator/project manager, a decision maker, a supervisor, another (which) role? How often do you meet suppliers face to face? If so, what kind of purchasing do you do? To the professional B2B buyers: Direct or indirect purchases, or a combination of both? How many years do you have working experience? How many years have you already been active in procurement/purchasing for this organization? Have you held other purchasing positions before?

\section{Buying process}

What kind of things do you value in buying process? Could you come up with three most important things? Examples, please. What kind of things do you value in buying process? Could you come up with three most important things? Examples are welcome. What kind of activities proceed your buying process? What kind of activities by the supplier are constraints for your buying process? What kind of information sources are you using when you are sourcing for services? Do you make a distinction between the sources you use for different kind of purchases? Have you used companies' website information while sourcing/purchasing? What about social media services or other digital tools? How do you think these tools constrains or proceed your buying process? When you are sourcing/purchasing, how much are social media and digital channels helping to create value for you and for your firm? What is currently causing most challenges in buying? Could you come up with a top 3 of most important things? Examples welcomed. How do see this is changing in the future? What are the main obstacles for purchasers for utilizing social media and digital channels? As in personal buying? While buying on organizational level?

\section{Online dialogue}

How many companies were researched via online tools before you decided to meet these XYZ companies? In the beginning of your search, how did you narrow down the set of companies you considered as potential suppliers? What kind of digital channels did you use to find information about XYZ services? (Webpages? Forums? Vlogs? Linkedin? Twitter? Other?) What kind of value did the digital channel create for you? How did this proceed/constrain your buying process? Is it valuable to you if the CEO, the sellers, or other employees from the supplying company are active on social media? How valuable is this for you? Were other person's opinions influencing the set of companies that you considered to contact? If yes, what is your relationship with these people? How will you search the necessary information for your next step in the buying process? (Via webpages?) What kind of information do you need to continue in your buying process? What was the most useful content in the digital channels you used? In which digital channel? If it was not useful, what was missing? How should social media be used by selling companies? What kind of tools should they be using? Based on the information you have found online, would you already be able to make a purchasing decision? Yes, why? No, why not? How strong are your buying intentions now (before the meeting with the supplier)? If strong: Did you already take your buying decision? From a consumer perspective (B2C), what kind of web services could also work in B2B buying?

\section{Expectations towards sales meetings}

How did you discover the need to buy X services? Have you already had some previous contact with $\mathrm{Y}$ company? How did you get to know this company? Why did you contact this supplier? Why do you want to meet this supplier? Why are you organizing or accepting the meeting with the potential supplier? What are your expectations for the meeting? How do you think this meeting will proceed / constrain your buying process? What are the advantages of having this meeting? What happens if you do not achieve this/these result(s)? How would this affect your buying process? What kind of possibilities does the salesperson have to proceed the buying process? What are some of the best and worst practices for first sales meetings? In which phases do you think it is important to meet B2B salespeople personally? When do you think it is better to meet digitally? Would you like to add something? 


\section{Appendix 2: Coding Chart}

\begin{tabular}{|c|c|c|c|}
\hline Main Theme & Number & Subcategory & Quote Example \\
\hline \multirow{5}{*}{$\begin{array}{l}\text { Importance of } \\
\text { accessible } \\
\text { information }\end{array}$} & 1 & $24 / 7$ available information & $\begin{array}{l}\text { Often I do it [online shortlisting] at five or six o'clock } \\
\text { in the morning after I have woken up. I take care of } \\
\text { that kind of office work at that time, it's quiet and so, } \\
\text { but you can't call anyone since no one is at work yet. } \\
\text { Customer of a Telecom service provider }\end{array}$ \\
\hline & 2 & $\begin{array}{l}\text { Easy to use channels of } \\
\text { information }\end{array}$ & $\begin{array}{l}\text { (negative) } \\
\text { I always feel it's a bit difficult when I go there } \\
\text { [supplier's portal] only once every six months. } \\
\text { Customer of a Telecom service provider }\end{array}$ \\
\hline & 3 & Multichannel availability & $\begin{array}{l}\text { You kind of have all channels in use then [when } \\
\text { shortlisting]. Customer of a Telecom service provider }\end{array}$ \\
\hline & 4 & $\begin{array}{l}\text { Responsiveness of the } \\
\text { sales organization (chat, } \\
\text { automated email, phone } \\
\text { call) }\end{array}$ & $\begin{array}{l}\text { Q: Do they answer more quickly through social } \\
\text { media? } \\
\text { A: Yes. Prospective customer of an IT company }\end{array}$ \\
\hline & 5 & $\begin{array}{l}\text { Delivery tracking and } \\
\text { ordering system }\end{array}$ & $\begin{array}{l}\text { (negative) ---And when you order something, you } \\
\text { never hear from customer service, and you can't see } \\
\text { how the order proceeds, whether anything is } \\
\text { happening. Customer of a Telecom service provider }\end{array}$ \\
\hline \multirow{7}{*}{$\begin{array}{l}\text { Importance of } \\
\text { comprehensive } \\
\text { information }\end{array}$} & 6 & Financial situation & $\begin{array}{l}\text { You would need to get insight on the size and the } \\
\text { financial health of a company from there [online]. } \\
\text { Prospective customer of an IT company }\end{array}$ \\
\hline & 7 & Contact information & $\begin{array}{l}\text { I was contacted via a contact form, that's not bad, it } \\
\text { saves my time when I don't need to find their phone } \\
\text { number. Prospective customer of a Health service } \\
\text { provider }\end{array}$ \\
\hline & 8 & Pricing & $\begin{array}{l}\text { Like then I know a bit about what's coming and have } \\
\text { some more specific information. Of course the price is } \\
\text { seldom given on the webpages, only some information } \\
\text { on how much resources it would require. Prospective } \\
\text { customer of a Health service provider }\end{array}$ \\
\hline & 9 & $\begin{array}{l}\text { References provided by the } \\
\text { supplier }\end{array}$ & $\begin{array}{l}\text { And I look, very carefully, if possible, for references. } \\
\text { What has been done and with whom. Prospective } \\
\text { customer of an IT company }\end{array}$ \\
\hline & 10 & $\begin{array}{l}\text { Peer references online and } \\
\text { offline }\end{array}$ & $\begin{array}{l}\text { In general, reputation and experiences, what others } \\
\text { recommend matters a lot. Prospective customer of a } \\
\text { Health service provider }\end{array}$ \\
\hline & 11 & Sustainability & $\begin{array}{l}\text { And that's where we found two E's for the project: } \\
\text { ergonomics and ecology. Customer of a Telecom } \\
\text { service provider }\end{array}$ \\
\hline & 12 & Product or service features & $\begin{array}{l}\text { Well you kind of have to have such product } \\
\text { information so that you can do comparisons for } \\
\text { example with our present case. Prospective customer } \\
\text { of a Health service provider }\end{array}$ \\
\hline
\end{tabular}




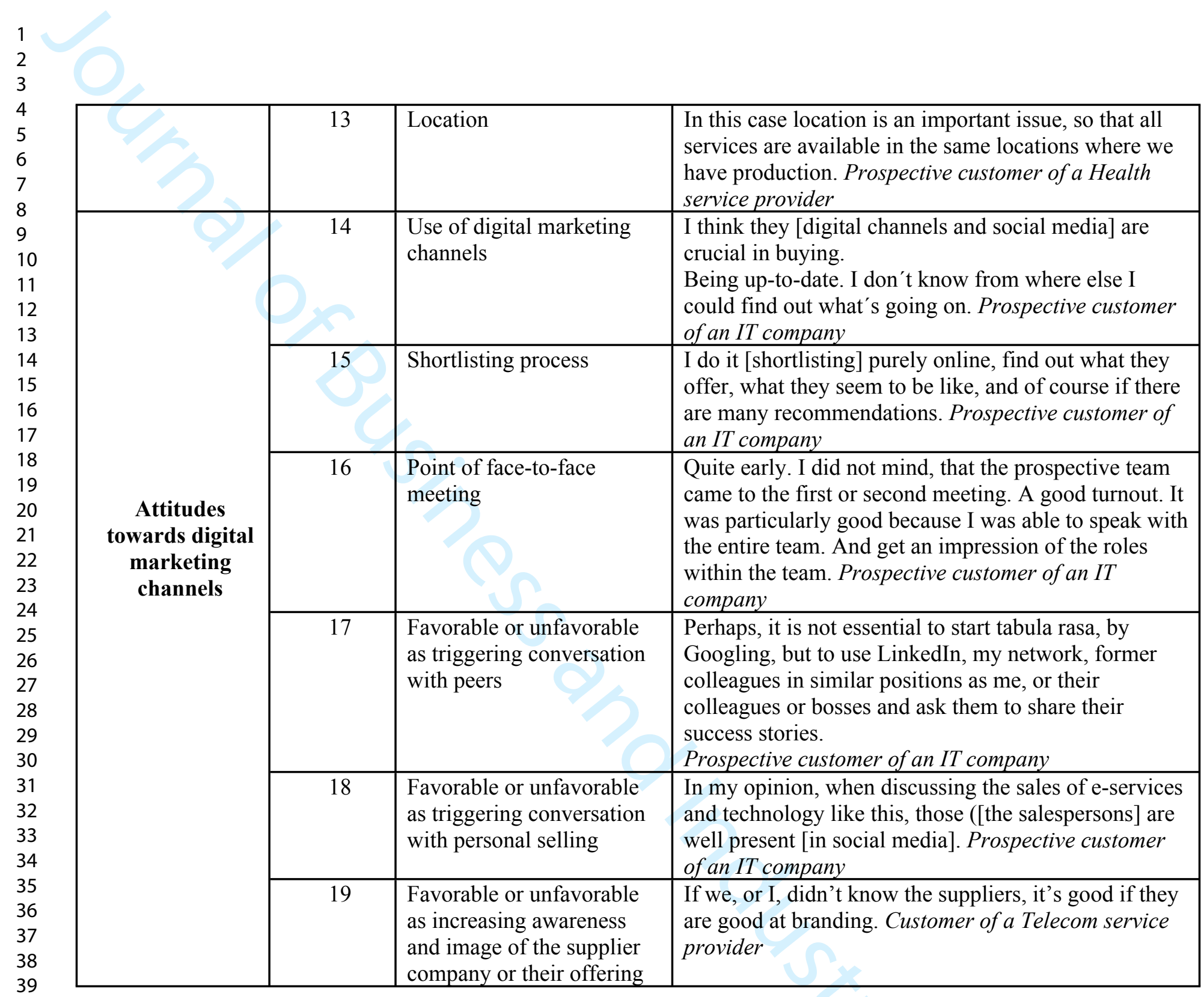




\section{Table 1: Channel Preferences by Buyers Depending on the Kraljic Matrix Quadrant}

\begin{tabular}{|l|l|}
\hline Kraljic Matrix Quadrant & Channel Preference \\
\hline Non-Critical (10) & $78 \%$ buyers preferred digital marketing channels. \\
\hline Leverage (21) & $\begin{array}{l}43 \% \text { buyers had a clear preference for digital marketing channels. } \\
\text { The remaining } 57 \% \text { required personal selling for the first meetings } \\
\text { and then change their preference to buying via digital marketing } \\
\text { channels. }\end{array}$ \\
\hline Strategic (3) & $100 \%$ buyers preferred personal selling. \\
\hline Bottleneck (1) & $100 \%$ buyers preferred personal selling. \\
\hline
\end{tabular}


Table 2: What Does the Buyer Desire from Different Channel Approaches

\begin{tabular}{||c|c|c|c||c||}
\hline & \multicolumn{3}{|c||}{ Buying Organization } & Selling Organization \\
\hline \hline & $\begin{array}{c}\text { Importance of } \\
\text { Accessible } \\
\text { Information }\end{array}$ & $\begin{array}{c}\text { Importance of } \\
\text { Comprehensive } \\
\text { Information }\end{array}$ & $\begin{array}{c}\text { Openness to } \\
\text { Having a } \\
\text { Personal Selling } \\
\text { Conversation }\end{array}$ & $\begin{array}{c}\text { Best-Suited } \\
\text { Channel Approach }\end{array}$ \\
\hline $\begin{array}{c}\text { Non-Critical } \\
\text { Products } \\
(10)\end{array}$ & ++ & ++ & -- & $\begin{array}{c}\text { Digital } \\
\text { Marketing }\end{array}$ \\
\hline $\begin{array}{c}\text { Leverage } \\
\text { Products } \\
(21)\end{array}$ & + & + & +- & $\begin{array}{c}\text { Digital } \\
\text { Marketing/Personal } \\
\text { Selling }\end{array}$ \\
\hline $\begin{array}{c}\text { Bottleneck } \\
\text { Products } \\
(1)\end{array}$ & - & - & ++ & $\begin{array}{c}\text { Personal } \\
\text { Selling }\end{array}$ \\
\hline $\begin{array}{c}\text { Strategic } \\
\text { Products } \\
\text { (3) }\end{array}$ & -- & - & ++ & $\begin{array}{c}\text { Personal } \\
\text { Selling }\end{array}$ \\
\hline
\end{tabular}

Ranging from very important $(++)$ to not important at all $(--)$. 